«Keruen» scientific journal

M.O.Auezov Institute of Literature and Art

ISSN 2078-8134

Volume 1, Number 66 (2020)

https://doi.org/10.53871/2078-8134.2020.1-03

МРНТИ 78.08:801.81

\author{
P. T.Auyesbayeva ${ }^{1}$, T. K.Albekov ${ }^{2}$, K. B.Alpysbayeva ${ }^{3}$ \\ M.O.Auezov Institute of Literature and Art, \\ Almaty, Kazakhstan \\ e-mail: ${ }^{1} \underline{\text { ksaryarka@ inbox.ru, }}{ }^{2}$ tokhtar58@mail.ru, \\ 3alpysbaeva-k@mail.ru
}

\title{
WORDS OF ANCESTORS - MASTERPIECES OF KAZAKH WORD ART
}

\begin{abstract}
The article highlights the issues of scientific preparation and publication of the 100- volumes of Kazakh folklore "Word ancestors", published in the period 2004-2013, including issues of genre classification of folklore texts, principles of selection and preparation of each volume, as well as the place of this priceless spiritual heritage in the world's culture. Kazakh folklore - is a syncretic literary art, originating from ancient times and representing folk art-aesthetic, philosophical, moral and ethical outlook. In recent years, scientific editions of folk literature, publications for children and a wide range of readers have been published, that had been collected from numerous handwritten patterns of folklore creativity which is an invaluable spiritual heritage people. At the same time we should mention that folklore collections published in the 90th - early $2000 \mathrm{~s}$, covered only a small part of the rich folk heritage of Kazakhs. One of the main reasons for this was the pro-communist ideology of the Soviet political system that prevented from the development of national cultures. For this reason, hundreds of folklore religious works, works with the sence of some ethnic patriotism, freedom and independence have not been included into scientific turn over and library circulation. However those works that have been published in the Soviet period, underwent censorship and abbreviations. The main purpose of the publication was the idea of demonstrating not only the richness of Kazakh folk literature, but also implementation of publication in accordance with modern requirements of philological science, also it was important to visibly show the antiquity of the origin of national culture.
\end{abstract}

Keywords: method, dastan, epic, version, variant, genre, folklore, textual studies, publication, manuscript.

Introduction. The Kazakh national monuments of oral poetry, the authors' of oral literary legacy represent the same national wealth as the wealth of Kazakhstan subsoil, fertile fields, the unique nature and countless herds of cattle. The patterns, spiritual values transmitted from generation to generation, are only a part of the huge folk heritage which survived to the present day and are stored in the National and Central Scientific Library of Kazakhstan, in the foundations of rare books of the Institute of Literature and Art named after M.Auezov, Central State Museum (Albekov, 2011). The main part of folk literature have not been recorded and systematized. The reasons for this should be searched in the history of Kazakh people who had undergone tremendous social and political events over the past three centuries. First of all, it's endless wars with Central Asian states, China, especially Dzungar invaders, since the formation of the Kazakh Khanate and a big role was played by the traditional nomadic lifestyle. And although in this period there were many heroic legends and historical epic, lyrical poems, legends, eloquent statements of wit persons, short stories and novels, as well as other genres of literature, none of them was recorded at that time and almost not published (Kazakh manuscripts, 1975-2013). 
Although in the XIX and to the nineties of the XX century the folk creativity has been collected, systematized, studied and published, and for its full disclosure the colonial censorship of Russian Empire and Soviet totalitarian system was a barrier (Words of ancestors, 2006). The genealogic annals-shezhire (Words of ancestors, 2012), religious epics (Alpysbayeva K.B., Auyesbayeva P.T., 2004, 13-18), hikayat and stories (Words of ancestors, 2013), historical narratives associated with national liberation movement (Words of ancestors, 2013), patterns of traditional folklore, personal creativity (works of akyns-zhyrau, biys and wits, poets improvisers and bards) have been especially subjected to ideological pressure, their texts were recorded incompletely and published only after a thorough check of censorship in accordance with the ideological requirements.So, those that did not pass them were put in the foundations for years.

Only when the country gained independence, due attention has been paid to the spiritual values of the people. However, the possibility of collecting materials on folklore and author oral literature were limited because many old people of the older generation have passed away, and they have kept these works in their memories. However, all conditions have been created for deep and maximally full studying of the literary monuments, already without censorship and changes in the text (Manuscripts of the Kazakh epos, 2011).

On the basis of the edict of the President of the Republic of Kazakhstan on the implementation of the State program "Cultural Heritage", in 2004 began preparation and publishing of 100 volume series "Babalar Sozi" ("Words of ancestors" ) («Words of ancestors», 2012, 12-17).

The Scientific Council of the Institute decided to start this multi-volume edition with epics - dastans. The thing is that big amount of them have been conserved in the foundations of rare manuscripts and rare books of the republic, and 70-80 percent of them have not been published, for the reasons mentioned above.

First, the activities on systematizing of works prepared for publication on genre specifics was undertaken, a full list was prepared. Since the scientific publication was planned, the priority was given to the compilation of scientific reference system. Under the leadership of prominent folklorist, academician S. Kaskabassov the scientists agreed and suggested to include the following: scientific comments to the texts, geographical dictionary, information about historical figures included in these texts, information concerning the collectors and compilers of the texts, a list of references and expressions used in Russian and English languages.

The peoples of Kazakhstan, especially Kazakh people have many cultural monuments of world importance. Most of these works are zhyr and epics - poetic stories and poems. These works appeared in different periods of Kazakh history, their authors are forgotten, and were transmitted orally during centuries from generation to generation, they have preserved in folk memory. On this centuries long way, they have not been fully preserved, and sometimes the tradition has interrupted. Therefore, in the repertoire of works of akyns-zhyrau and storytellers zhyrshy they survived as dozens of patterns and versions (Zhusipov, 2009). Throughout the history of Kazakhstan, these works have deeply penetrated into the minds and hearts of people, educating in people a sense of patriotism and love of country, justice, sincere faith, harmony and unity, pure love. We all know how scarce is documentary historical information relating to the history of our nation in XV-XVIII centuries, and it represents exceptional rarity, so the information and facts on state political system, public and social structure, history and culture, diplomacy and historical figures have reached nowadays also from patterns of folklore and akyn literature.

Methods. In preparation for the 100-volume series of Kazakh folklore "Word of ancestors" plot and typological features of Kazakh folklore are defined.

Various techniques developed in the system of Philology: textual, comparative-historical, source study, paleography, bibliography, linguistic folklore, documental, comparativetypological and others in the course of the study were used.

One of the main methods of textual research is the method by which focused on identifying the main options of folklore. To this end, special attention was paid to studying the history of 
folklore texts, of their existence, from generation to generation, history of written record, publication and publishing; distinctive features of manuscripts and printed works of artic work, features of various texts and forms of the records; identification of data about writers, storytellers, owner of the manuscript, and others.

Textual method involves finding information about the differences of the same product depending on the individual abilities of the performer (sometimes differences in the texts of the same narrator), in this sense, the study of subjects which is underwent reduction or vice versa to supplement, interaction and interdependence of the characters of work, geographical names, in different versions of texts; syncretism approach when recording a work on paper or another (tape recorder etc.).

The basis of the comparative-historical method is based on the principle that allows to identify and to clarify the reality of the origin of the characters of folklore works of large forms, in particular to obtain new historical data about the life and work of khans and sultans, national leaders-warriors, biys, elders of the Kazakh tribes, as well as their artistic interpretation in the works. The method helps to build a reliable chronology of historical events, the elucidation of historical sources concerning the life of historical figures, the genesis of the origin of products, their development and transformation into a tradition.

In the study of the history of collecting of folklore heritage all the richest source base in the form of documents preserved in libraries, archives - it's all kinds of historical records, memoirs, letters, book publications, etc. was taken into account. Hence the special importance of the source method is highlighted. Thus, the methods used in the study made it possible to carry out a comparative historical and typological analysis of the works, which significantly raised the level of scientific publication.

One of the important methods that strengthen scientific research base is a method of records. It is very important when dating tales play documentary-narrative materials, such as, for example, official papers of khans and sultans adopted during their rule, decrees and resolutions, documents on external relations of the rulers with foreign states and metropolitan, photos and others. Thanks to document study method it can be done scientific conclusions about the history of the origin of specific products.

When it comes to related Turkic peoples, we observe the law-governed pattern similarity of many historical figures, historical events, traditions, most notably in the folk heritage. In this sense, the typological method allows to carry out comparative analysis of many folklore works, having wide circulation among the Turkic peoples, indicating the similarities and differences between them.

In textual study of folklore heritage paleography method is of great importance. Paleographic method focuses on the study of ancient texts in writing, in particular, handwriting, alphabets, languages, ways of writing, periodization and attribution.

Results. The paper discusses scientific system of the edition "Babalar Sozi" (Words of Ancestors) in 100-volumes which includes a rich folklore heritage of Kazakh people, which preserved in the Great Eurasian steppe through oral transmission from generation to generation and during centuries formed a nomadic culture and continuously enriched it till the early XX century.

In the course of the research the role of this scientific publication in the world culture, especially in the spiritual life of the Eastern peoples, including Turkic-speaking peoples has been determined.

It should be noted that national values of Kazakh national identity, language, traditions, religion, history, ethnography, and in general, literature and culture have reached nowadays due to folklore heritage.

Unfortunately, colonial dependence of Kazakhstan from Russian Empire and later Soviet authorities -until the 90s of the XX century, constrained full collection and publication of this priceless national value at time. It should be especially noted that $80-90 \%$ of folklore texts which are explored and published in multi-volume series within the program "Cultural heritage" 
in the period from 2004 to 2013 under the title "Word of ancestors", have not been published previously.

The research work includes comprehensive study of scientific structure of the series, genre system of the works of each volume.

It should be noted that archaic patterns, texts of heroic, historical and lyrical epics, novelistic and religious epics, fairy tales and legends, oral stories, proverbs and sayings, as well as some of ritual folklore traditions, plots and motifs, included into the edition, show close features and similarity between folklore heritage of the Kazakhs and folklore of Turkic peoples, and moreover with the world folklore.

The main research aim includes the issues of genre systematization of folklore heritage, included in this multi-volume edition, scientific characteristics of their certain types, which will be interesting to contemporary researchers of folklore.

Discussion. Therefore volumes 1-9 of the 100 volume series "Words of Ancestors" published in 2004, were composed based on the plots of the Eastern peoples, the volumes include thirty-one work of novelistic dastan genre - epic stories and legends in a poetic narration (Albekov et al .., 2017). Publications include "Kissa Zeine Zayyp", "Orka-Kulshe", "Kissa Tahir", "Shahmardan", "Kissa Sherizat", "Karkabat", "Kissa Kasim Zhomart", "Kagira and Taymus", "Khikayat Salimzhan", "Bolat, Janat", "KissaJamshid", "Abugalisina, Abulharis", "KissaSamuruk", "Kissa kyrykuazir", "Kissa Shakir Shakirat", "Baktiyar Kissasi" etc.

In 2005 10-16 volumes were publishing included forty three religious dastans, which were not published after the October Revolution due to censorship reasons, and they remained inaccessible to readers. Among them there are folklore works "Kissa Zarkum", "Gazauat Sultan", "Kissa Salsal", "Aziret Alidin sogysy", "Kissa Abushahma", "Kissa Seyitbattal", "Kissa Malikkazhdar", "Kissa anhaziret Rasuldyn Migrazhga konak bolgani", "Muhammad Payghambar","Kissa uakiga Kerbala ushbu-dur", "Kissa Mansur al-Halazh", "Dariga kiz", "Kissa Shahizinda", "Kissa Zhumzhuma", "Haza Kitap Mohammed Khanafiya", "Mohammed Kanafiya" etc.

In the same year 17-22 volumes of the series were compiled - "Romantic dastans" and the readers got an opportunity to familiarize with nearly thirty earlier unknown works of literary heritage. Among them we can distinguish dastans "Kissa Leili-Mazhnun", "Kissa Tahir-Zuhra", "Bozzhigit", "Seypilmalik", "Kissa Sherizat-Kulshat", "Kissa Shahizada", "Amirzada" etc.

Since 2006, we began studying folk heritage of overseas compatriots, offered them to readers' attention and included them in scientific use. Group of compilers worked with great responsibility, for the first time prepared for publication a collection in ten volumes of folklore works of Kazakhs living in China. Volumes 23, 24, 30, 31 included" Novelistic epics", 25-26 volumes "Romantic dastans", 27, 28, 29 volumes - "Historical Poems", and the last 32 volumes were dedicated to "Genealogical poems".

We would like to note the great contribution to the preparation of ten volumes of the series of the Honored Chinese scholar, writer, member of society of folklorists of China, professor Orazanbay Egeubayev. He has been a tremendous help in collection of texts, clarifying their origin, especially in collection of information about the authors of dastans and performers.

A huge part of Kazakh folklore heritage of ancient time consists of heroic tales that transmitted from generation to generation a feeling of patriotism and love for the motherland, unity and harmony of the people. They reflect the struggle of our people for independence and integrity of the Nogay and Kazakh horde between XIV-XVII centuries, and high feeling of love of young hearts. Therefore 33-52 volumes of the series "Words of Ancestors" are devoted to the heroic epic. For example, in the above-mentioned funds, along with the variant (Words of ancestors, 2013) "Alpamys warrior" published by J. Shaikhislamuly in 1899 in Kazan there are more than ten versions of the text of this poem. Although this work was published several times in the Soviet period, during editing different versions of the texts have been combined. Taking this into account, the compilers considered to keep them unchanged in 33-34 volumes, which 
include thirteen versions. This gives the readers the opportunity to read the original texts of manuscripts.

It is no secret that the same mismatch of texts was observed in editions of the epic "Koblandy warrior". Therefore we collected all versions, about thirty of them, which have reached nowadays, systematized, and 16 variants were included into the volumes 35-38. Amongthem there are patterns which were previouslyunfamiliar to the readers.

In Volume 43, along with previously unpublished versions of the epic "Kambar warrior" nine of his previously unknown variants readers are published. A 44 volume contains epics "Er Kokshe", "Ep Spit", "Saiyn warrior", "Karabek warrior" and several versions of "Er Targyn" etc.

Substantial part of "Warriors Legends" is the cycle "Forty warriors of Crimea" of Nogai period in XIV-XVII centuries. 50-51 volumes of the series include thirty six works of the famous Muryn zhyrau Sengirbayuly, and there are textual comparison to their published versions. Such poems as "Edige", "Orak -Mamay", "Shora", "Karasay-Kazi" are included in separate volumes. For example, volume 39 contains stories about Edige, $40^{\text {th }}$ volume - about Orak and Mamay.

In rare funds there are kept nearly thirty variants and versions of the epic "Karasay-Kazi" which distinguish in the plot structure and composition, as well as language and style of narration. They also have distinctive features in the interpretation of the theme, and they are very different in description of particular events. Group of compilers has done their textual analysis and selected for publication twelve versions. They are included in the volumes 41, 42 and 46 of the series (The features of variants of poem «Karasay-Kazi», 2013).

Versions of epic "Shora warrior" from the cycle "Forty warriors of Crimea" which is widespread among the Turkic peoples (Kazakhs, Nogay , Crimean Tatars, Tatars, Karakalpaks, Kirghiz) and has been early noticed by European scientists, have been included into volume 45, five epic works devoted to the heroic life and deeds of brave warrior Bozuglan, Zhusip and Ahmet have been included into volume 47 . Volumes 48 and 49 include legends devoted to the legendary Batyr Korugly (Kerogly).

One of the genre varieties of heroic legends is archaic epic, consisting of fabulous and mythical events and legends, which artistically reproduce beliefs of ancient people around the world and their relationship with nature. They include works in volume 52 such as "Khikayat risala Munlyk Zarlyk", "Kissa Dotan Kubakanbayugly", "Kissa Kulamergen", "Kubygul" etc.

Kazakh folklore includes novelistic (love) poems, dedicated to pure and selfless love of the young people. They were often published in the Soviet and pre-Soviet times and were very popular among the people. Today, the foundations of Kazakhstan have about thirty versions of the poem "Kozy Korpesh - Bayan Sulu" (besides Kazakh people, the plots of this poem also exist in Bashkir, Altay, Yakut, Teleut, Baraba Tatars and other Turkic peoples), and there are more than fifteen versions of the poem "Kiz Zhibek" (Kissa Kiz Zhibek, 1900).

Volume 53 includes five versions of the epic "Kiz Zhibek" which were previously unknown to the readers, and volumes 54-55 - twelve versions of the epic "Kozy Korpesh Bayan Sulu".

Historical songs are the integral part of Kazakh folklore, many of them are devoted to the heroic struggle of the people for freedom and independence, serving as an example of true patriotism for future generations. As we know, during the Soviet period there were restrictions on studying national liberation ideas" (Problems of the Kazakh epic, 1953, 97-98).And only in the period of independence, in Kazakhstan has appeared an opportunity to give an objective assessment of the country's history, to reveal the real content of literature and culture of the Kazakh people. It is very good that the initiative to publish most of the existing spiritual heritage has received financial support. 56-63 volumes of the series "Words of Ancestors" includes historical legends.

These volumes include historical stories about Kazakh khans Yesim, Abylay, Kenesary and others, including Janibek Khan (XV c.), as well as historical stories about dozens of batyrs and military leaders such as Olzhash, Satbek, Orakty, Bogenbai, Kabanbai, Zhasybai, Zhidebay, Olzhabay, Rayimbek, Otegen, Myrky, two Janibeks, two Baraks, Berdikozha, Bazar, Jantay, 
Syrym, Azhibai, Arkalyk, Zhankozha, Agybay, Bayseit, Myrzash, Aidos. Subsequent volumes of the 100 volume series "Babalar Sozi" are dedicated to small genres of Kazakh folklore, and their publication began with genre of riddles. "Witty riddles are expressed with artistic expression and deep sense and mostly presented in verse" (Gabdullin, 1972). They teach the younger generation of children to be resourcefulness and have sharpness of mind, awaken their minds and feelings, enhance their self-awareness, to learn the surrounding world. The puzzles show the philosophy of the people who created them, literary and aesthetic level, the level of social consciousness, the development of their mind and language. Volume 64 which represents this genre includes 2279 puzzles, preserved in the manuscript collections of the country, recorded from people, and collected among Kazakhs in foreign countries.

Subsequent volumes 65-69 consist of proverbs and sayings. Throughout the rich spiritual and social experience of people's life and due to brilliant talent of gifted representatives, thousands of proverbs and sayings have been published. Most of them were composed and used in ancient times by witty and resourceful people (Explanatory dictionary Kazakh, 2009, 88) and became popular among people, and became part of their spiritual heritage. Kazakh proverbs serve as a model of literature which has delicate and deep meaning. Proverbs and sayings are not only spiritual wealth of the nation and witness of centuries-old culture, but also a unique chronicle of the formation of national consciousness and genius.

Proverbs and sayings included in the first volume 65, have been collected as a result of folklore and ethnographic expeditions in all regions and corners of the country within the framework of the "Year of national unity and national history" announced by President of the Republic of Kazakhstan Nursultan Nazarbayev in 1998. Volume 66 includes brilliant sayings of Bilge Khagan, Tonykok, Kultegin and other rulers, warriors and biys carved on stones during ancient Turkic period and during Middle Ages which were included in the manuscript and have become proverbs and sayings which are found in the writings of Zhusip Balasaguni, Mahmud Kashgar and others (Kuryszhanov, 1987). Contents of volume 67 includes proverbs collected among Kazakhs living in People's Republic of China. Volume 68 includes national heritage beginning from the middle of XIX century to the second half of the XX century, and volume 69 includes literary monuments, preserved in rare collections of the libraries and institutions. Texts of all proverbs are numbered, and in the end there are patterns which have been changed during different periods.

Volumes 70-71 are devoted to the following folk poems, which preserved among the Kazakhs since ancient times. Among the nomadic Kazakh people it was impossible to meet boys and girls, who would not know the white verses. This explains the large number of poetic heritage, scattered among various funds, where they occupy a significant place. "White verses" refer to the traditional syncretic genre associated with songs and melodies.

Children's folklore is a traditional pedagogical value, which aims at education of the younger generation (Islamjanuli, 1995, 128), formation of their minds, aesthetics, philosophy and psychology, forming love to hard work from an early age, love of country, awakens and stimulates the creative abilities of children. The themes of these works, the style and artistic images play a special role in the formation of the spiritual world of younger generations. Volume 73 contains this literary heritage of different periods and collected from different parts of the country. It also includes comments and different versions of the texts .

Researches of Academician S.Kaskabassov showed that the genre of fairy tales included into volumes 73-77 volumes of the series, is one of the most advanced artistic genres of folk literature and demonstrates the highest achievements of literary art. The purpose of this genre together with exciting instructive plot is to give aesthetic satisfaction to the listener. The impact of fairy tales has a broad scope: they play an educational and artistic-aesthetic role. Genre feature of folk tales consists of these two components. Therefore, the main task of a fairy tale is to make the story plot attractive, transfer it lively and colorful. Of course, fairy tales do not pretend to be a truthful transfer of the realities of life, and the storyteller doesn't strive to persuade the listener in this (Kaskabassov, 2008, 258). 
Kazakh tales are multifaceted in terms of genres and subjects. They are divided into several subtypes: animal tales (73 th volume), tales about miracles (volume 74), heroic tales (vol. 75), tales-novels (volume 76), satirical tales (volume 77). In their plot stories, along with plot typical only for Kazakh tales there are also plots from tales of other nations. Most of them are historical- typological, some are historical-genealogical - they are similar to the related Turkic peoples, and spread among the Kazakhsin the result of close historical and cultural ties. For this reason, among the Kazakh tales coexisted purely national and international plots, so-called "roaming".

Genre of myths included into volume 78 have appeared at the dawn of mankind, gradually evolved and rose to the level of artistic works. Especially cosmogonic and etiological myths have widely spread which clarify the existence of heavenly world and reveal some of the qualities of animals. When people were composing numerous myths about human nature, structure of the universe, they have tried to understand and explain it all, and transferred their lives, customs and traditions to these myths, explaining many things by their daily occupations and lifestyles, linking them with human qualities.

We have already mentioned that the compilers of the series "Word of ancestors" tried to cover folk heritage of our compatriots abroad, and therefore, efforts have been made to collect folklore in neighboring countries, then they were systematized and prepared for publication. Part of this heritage is devoted to the folklore of the Kazakhs of Mongolia. Collection of folklore of Mongolian Kazakhs is included in volume 79 and is prepared on the basis of patterns of folklore collected among the Kazakhs in Bayan Olgiy district.

The following volumes 80-89 of the series "Word of ancestors" are devoted to a large part of Kazakh folklore - legends. The initial volume contains toponymical legend. This genre includes stories about the origin of the names of lands and reservoirs, rivers and lakes, mountains and rocks, etc. This volume contains materials collected and recorded during scientific literaryfolklore and ethnographic expeditions among Kazakhs in China (Auyesbayeva, 2014, 71-74; Fairy tales Morei, 1999), as well as stored in the manuscript collections of Kazakhstan.

It is known that general genealogical chronicle "shezhire" of the Kazakhs consists of shezhire of particular tribes and clans, Tore and Kozha, Tolengitov. Within the genre, they are divided by the following features: - poetic shezhire -legend, shezhire written in blank verse and shezhire as a genealogical table. Since shezhire was in demand in administrative system of Kazakh horde, the khans collected them, systematized and recorded on paper - knowledge of shezhire helped form and equip troops through tribal warriors, implement policy through the rulers and biys of clans and tribes, as well as used in addressing emerging land and personal disputes, tax collection.

Legends shezhire which were transmitted orally from generation to generation - is the centuries-old history of the Kazakhs, a reflection of the way the formation and development of the nation. Besides tables of genealogical tree, the genealogy of each tribe, clan, dynasty was replenished with legends associated with them, which have been transferred from generation to generation and constantly replenished. Later, based on different stories told by the elder people and prose legends, the akyns and zhyrau created poetic stories. Most of them were not limited to specific plot, but covered genealogy of proto-Turks, ancient roots of Kazakhs to present period. Volumes 81-82 of the series are based on the works, telling about the origin of the Kazakhs, beginning with Adam, Turkic Khanate, Alash Khan, Maiky Biy, the history of three zhuzs, some tribes and clans.

Prosaic genealogical legends (volume 83) - they figuratively and artistically tell about the great personalities who have played a role in the history of ancient Turks, Oguz, Moguls, Nogai, Tatars and united the tribes into one nation: Oguz Khan, Genghis Khan, Alash Khan and describes the origin of the self-name of the people "Kazakh" and battle cry "Alash", the division of people into three juz, origin of particular clans and Tore, Sahaba, Kozha, shalakazakhs, Tulengut people who were not included into Kazakh tribes but participated in the formation of nation, the stories and legends about the formation of Kazakh people. 
Kuy legends - is a kind of spiritual phenomenon in Kazakh culture. They occupy a special place in the spiritual heritage of the people and are traditional heritage with the roots going back to the old period. The evidence of this is the art of kui which originated from great storyteller Korkytata and continues at present day. We should mention about the inextricable link between kui and kuishi, kui and legends, stories of origin of kui and performers. Volume 84 of the series "Babalarsozi" includes legends of VIII-V centuries BC - VI century AD ("Kos muyzdi Eskendir", "Kok Tobet", "Kokbori", "Akku", "Saryn", etc.), and legends that have appeared during the VII-XIX centuries associated with the creativity of famous kuishi of that time or folklore.

Volumes 85-88 are dedicated to one of the oldest genres of folklore - historical legends (VI-XIX). Many legends associated with the names of brave warriors - fighters for independence of homeland, shows examples of devotion and service to the nation remained neglected until gaining independence, and not published because of prohibition, and for this reason they have not been promoted and studied. That's why a special attention was paid to them in the preparation of this publication. Texts of historical legends have been published thanks to those which preserved in the collections of rare manuscripts of the republic.

Volume 89 of the series presents patterns of legends in verse. Among them there are such big folklore works as poem-legend "Kizkulagan", based on a fairy-tale plots "Aldar Kose" depicting historical figures of the legends "Korkyt", "Asankaigy."

Ceremonial folklore refers to the most well-preserved genres of Kazakh folklore. This type of folklore art is based on description of life, activities and practices, social relations, traditions, beliefs, professional activities and other values in life. It is known that this genre is constantly updated and developed. The main types of this genre include: calendar ritual (zhyr about nauryz, Ramazan), wedding ceremonies (matchmaking, toybastar, songs zhar-zhar, synsu, aushadiyar, betashar, nekekiyar), funeral (zhoktau, dauys, konilkos, korisu, etc.). Volume 90 includes seasonal, traditional and wedding folklore, and volume 91 includes samples of remembrance folklore.

A special place in Kazakh folklore take tall tales, fables in verse and prose samples. The first goal of tall stories - is with the help of unbridled imagination, ingenuity and sophistication, colorful language to capture the audience and excite their imagination, and the second - to cheer up people by interesting, funny and amazing events (Zhansugiruly, 1927, 5). Fables in verse (also prose samples) transmit any occasion or event in allegorical and didactic form, to show negative sides of any action. Volume 92 includes works of this genre, which certainly will be of interest to readers.

Magic folklore (volume 93) - one of the most interesting branches of national heritage which has cognitive and educational meaning. It is divided on manner and tone of narration, poetic form and artistic realization, features of content on the following sections: blessing, curse, dream interpretation, prohibitions, prayers, incantations, prayers, shamanic songs, spells, divination, voodoo rites of purification, etc.

Like other peoples of the world our people have other types of magical folklore - dreams and their interpretation, and superstition. Volume 94 includes various samples of dreams and their interpretation, related superstitions, but since all the texts could not be included in a single volume, they have been included in systematic form only excerpts and some samples of superstitions.

Another type of prose legends are hikayats (hagiographic stories). Their plots and themes are divided into books and religious. Hikayat include various works written on the basis of the life of the prophets and saints and Muslim mythology. Volume 95 includes works of Adam Suleiman, the Prophet Muhammad, Lukpan, Eskendir Zulkarnay, Kydyr and others which are widespread among Kazakhs. Sixth and seventh collection of the remaining ten volumes of the series are devoted to "oral stories" (volumes 96-97), the eighth collection (volume 98) to the stories about Kozhanasyr and other Kazakh stories about dodgers. These stories are based on the interesting content in terms of 
humor events in social life or individuals. Usually these stories are related to the narrator or person familiar to the audience, more precisely, mostly the narrator himself is the main character.

Folk song heritage of Kazakhs is distinguished in broad range of themes and variety of content. Mostly - different aspects of people's life, a reflection of social relations, state of human soul, unfulfilled dreams and desires, customs and traditions, young people's pure love, grief and sadness, secrets and mysteries of nature. Therefore folk songs transfer ethical ideas, aesthetic and human feelings to listeners. Samples of song heritage are included in the volumes 99 and 100.

The last volume 101 of the series "Word of ancestors" is representing a scientific-reference book to the whole publication - this is a system of bibliographies and comments to folklore materials published in 100 volumes.

In preparation of the 100 volumes series participated professor B.Azibaeva and a group of drafters led by $\mathrm{PhD}$ Phil. SciS. Kosan and T.Albekov represented by K.Alpysbaeva, P.Auyesbayeva, M.Shafigi, T.Akimova, Zh.Rakysheva, Zh.Saltakova, N.Mursalimova, N.Elesbay, A.Oralbek, Yu.Piltan and other researchers. Thanks to them the series "Words of Ancestors" in one hundred volumes has been completed successfully and timely.

Conclusion. Successful completion of this unique publication gives grounds to state that the program "Cultural Heritage" initiated by the Head of the State Nursultan Nazarbayevis fully implemented. This once again emphasizes the authority of independent Kazakhstan in international community, and collected Kazakh folklore will be introduced into the scientific use of world folklore and take its rightful place among the human values.

Secondly, it is worth noting that literary monuments, which have been laying in dust in the foundation storages, have been returned to people, and works published in the XIX-XX centuries, in Arabic, Latin and Turkish languages remained unknown until today to a wide range of readers. We are sure that unpublished folklore texts, their diverse samples will be included in the scientific use, and will be included in educational process. These books in the revival of spirituality and culture of the nation will become basic works, not only for scientists in philology, but also historians, linguists, philosophers and other scholars. We would like to express hope that this publication of folklore works will enhance strengthening of national identity and further flourishing of folk traditions coming from the depth of the centuries.

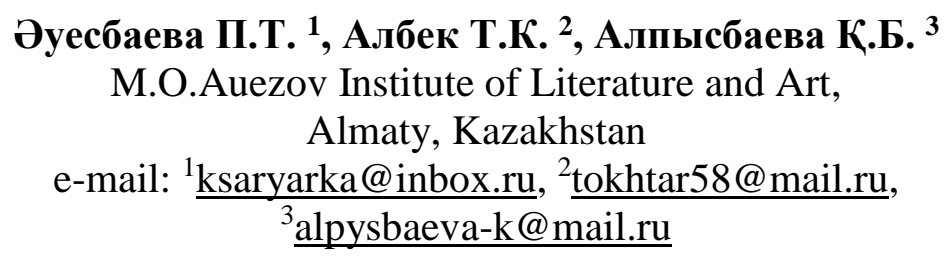

\section{«БАБАЛАР СӨЗІ» - ҚАЗАҚТЫН СӨЗ ӨНЕРІНІН ЖАУһАРЛАРЫ}

Аннотация. Мақалада сан ғасырлар бойы Евроазия ендігіндегі Ұлы даланы мекендеп, сол даланы көзінің қарашығындай сақтап қалған, көшпелілер мәдениетін қалыптастырып, өркендетіп, оны XX ғасырдың бас кезіне дейін жалғастырып келген қазақ халқының аса бай фольклорлық мұрасын бүкіл әлем жұртшылығына паш еткен «Бабалар сөзі» жүзтомдық сериясының ғылыми жүйесі сөз болады. Зерттеу барысында ғылыми басылымдардың әлем мәдениетіндегі орны, әсіресе Шығыс халықтарының, оның ішінде түркі тілдес ұлттар мен ұлыстардың руханиятындағы маңызы аталып өтті. Қазақ халқының ұлттық болмысының, тілінің, әдет-ғұрпының, салт-санасының, дінінің, тарихының, этнографиясының, жалпы әдебиеті мен мәдениетінің негіздері фольклорлық мұралар арқылы жетті. Өкінішке орай, Қазақстанның XIX ғасыр мен XX ғасырдың 90жылдарына дейін алдымен Ресей империясының, кейін Кеңестер одағының бодандығында болуы - ұлттың рухани құндылықтарын толық жинауға, қорларда сақталып қалған мұралардың өзін жарыққа шығаруға мүмкіндік бермеді. «Мәдени мұра» мемлекеттік 
бағдарламасының негізінде 2004-2013 жылдары жарыққа шығып, осы зерттеуге ғылыми нысана болған «Бабалар сөзі» көптомдығының басты ерекшелігі - оған енген фольклорлық мәтіндердің 80-90 пайызының бұрын басылым көрмегендігінде болды. Сол себептен зерттеуде серияның ғылыми құрылымы, әр томда қамтылған халық шығармаларының жанрлық жүйесі іргелі түрде, жан-жақты қарастырылды.

Жинақтарға енгізілген көне, батырлық, тарихи жырлардағы, ғашықтық, новеллалық, діни дастандардағы, ертегілер мен аңыздардағы, ауызекі әңгімелердегі, мақалмәтелдердегі, ғұрыптық фольклордағы кейбір оқиғалардың, сюжеттердің, мотивтердің түркі халықтары, тіпті әлем елдерінің фольклорлық мұраларымен ұштасып, бір шығарманың бірнеше ұлттық варианттары мен версияларының ұшырасып жатуы - қазақ руханиятын бүкіл әлем мәдениетіне жақындата түседі. Сондықтан да зерттеудің негізгі мақсаты көптомдықта қамтылған фольклорлық мұраларды ірі-ірі жанрларға топтастырып, олардың ғылыми сипатына көңіл бөле отырып қазақ фольклорына қызығушылық танытушы әлем ғалымдарының азды-көпті мәлімет алуына мүмкіндік жасау болды.

Кілт сөздер: әдіс, дастан, эпос, версия, вариант, жанр, фольклор, текстология, жарияланым, қолжазба.

\section{Әуесбаева П.Т. ${ }^{1}$, Албек Т.К. ${ }^{2}$, Алпысбаева Қ.Б. ${ }^{3}$ \\ M.O.Auezov Institute of Literature and Art, \\ Almaty, Kazakhstan \\ e-mail: ${ }^{1}$ ksaryarka@ inbox.ru, ${ }^{2}$ tokhtar58@ mail.ru, \\ 3alpysbaeva-k@mail.ru \\ «СЛОВА ПРЕДКОВ» - ШЕДЕВРЫ КАЗАХСКОГО СЛОВЕСНОГО ИСКУССТВА}

Аннотация. В статье рассматриваются вопросы научной подготовки и издания 100томной серии казахского фольклора «Слово предков», выпущенной в период с 2004 по 2013 гг. В том числе вопросы жанровой классификации фольклорных текстов, принципы отбора и подготовки каждого тома издания, а также место этого бесценного духовного наследия в мировой культуре.

Казахский фольклор - это синкретичное словесное искусство, берущее свое начало с древнейших времен и воплощающее собой народное художественно-эстетическое, философское, морально-этическое миропонимание.

В последние годы в свет были выпущены как научно-академические издания народной литературы, так и издания адресованные детской аудитории и широкому кругу читателей, вместе с тем несколькими поколеними ученых, в результате многолетних изысканий были собраны многочисленные рукописные образцы устного народного творчества, являющееся бесценным духовным наследием народа.

Изданные в 90-е - начале 2000-х тысячных годов фольклорне сборники охватили лиш малую часть богатого фольклорного наследия казахов. Одной из главных причин этого была исключительно идеологизированная советская прокоммунистическая политическая система, препятствовавшая развитию национальных культур. По этой причине в научный и читательский оборот не были введены сотни фольклорних починений религиозного содержания, произведения несущие в себе идеи народности, патриотизма, свободы и независимости.

Произведения, которые были опубликованы в советский период истории страны, подверглись цензурной чистке и сокращениям.

Основной целью издания стала идея демонстрации не только багатства казахской народной литературы, но и реализация издания в соответствии с современными требованиями филологической науки, также необходимо было зримо показать древность происхождения национальной культуры. 
Ключевые слова: метод, дастан, эпос, версия, вариант, жанр, фольклор, текстология, публикация, рукопись

\section{Information about authors:}

Ауесбаева П.Т. - ведущий научный сотрудник Института литературы и искусства им, М.О. Ауэзова, отдела «рукописей и текстология», к.филол.н., доцент e-mail: ksaryarka@inbox.ru, ORCID iD: ${ }^{1} 0000-0002-$

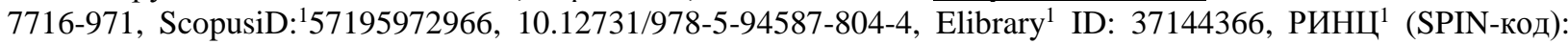
4655-9080

Албек Т.К. - ведущий научный сотрудник Института литературы и искусства им, М.О. Ауэзова, отдела «рукописей и текстологии», к.филол.н., e-mail: tokhtar58@ mail.ru, ORCID iD: ${ }^{2}$ 0000-0003-2481-663X, ScopusiD: ${ }^{257195976018 ;}$

Алпысбаева Қ.Б. - ведущий научный сотрудник Института литературы и искусства им, М.О. Ауэзова, отдела «рукописей и текстология», к.филол.н. е-mail: alpysbaeva-k@mail.ru, ORCID iD: ${ }^{30000-0001-8240-}$ 732X, ScopusiD:; ${ }^{3} 57195973247$

\section{REFERENCES}

[1] Albekov T. (2011). Golden Hole of Spiritual Treasures. Aikyn (kaz.).

[2]Alpysbayeva K.B., Auyesbayeva P.T. (2004). Text features of the version of the religious dastan "Seyitbattal" News of NAS RK, 2, 13-18 (kaz.).

[3] Auyesbayeva P.T. (2014). Some aspects of beginning in composition строe fairy-tales of turkic people: History and culture of the peoples of Couth-West Siberia and adjacent regions (Kazakhstan, Mongolia, China). Materials of the international scientificpractical conference (Russian Science Citation Index) (P.71-74). Gorno-Altaysk, Republic of Altai, Russia. (rus.);

[4] Tales of the Morey district (1999). China (kaz.).

[5] Discussions on questions of epos Kazakh (1953). Bulletin of Kazakh SSR. 8. $97-98$ (kaz.).

[6] Albekov T.K., Alpysbayeva K.B., Auyesbayeva P.T. (2017). «Distinctive and educational features of Kazakh folklore by the example of «Words of Ancestors»»). Revista ESPACIOS. ISSN 07981015 (Web of Science). Vol. 38, Issue 45, 33-43 (eng.).

[7] Explanatory dictionary Kazakh proverbs and saying (2009). China: Xinjiang (kaz.).

[8] Gabdullin M. (1972). Of oral national creativity of the Kazakh people. Almaty: Gylym (kaz.).

[9] Islamzhanuly K. (1995). Rukhaniuyz. Almaty: Ana tili (kaz.).

[10] Kaskabassov S. (2008). Etiologic fairy-tales. History of Kazakh literature. Ten volumes. 1 vol. Almaty: KazAkparat (kaz.).

[11] Kazakh manuscripts (1975-2013). Scientific Description of Kazakh Manuscripts. Almaty: Gylym (kaz.).

[12] Kissa Kyz Zhibek hikayasy (1900). Kazan (kaz.).

[13] Kuryshzhanov A. (1987). Words of ancestors. Almaty: Gylym (kaz.).

[14] Manuscripts of the Kazakh epos that reflect the idea of independence. (2011). Almaty: ID «Credos» (kaz.).

[15] The features of variants of poem «Karasay-Kazi»: Republican research and practice conference (2013). Aqtau (kaz.).

[16] Word of ancestors: One hundred tomnik (2006). Heroic Epic. V. 39. Astana: Foliant (kaz.).

[17] Word of ancestors: One hundred tomnik. (2012). Chronicles and Legends. V.81. Astana: Foliant (kaz.).

[18] Word of ancestors: One hundred tomnik. (2013). Hikayats. V. 95. Astana: Foliant (kaz.).

[19] Word of ancestors: One hundred tomnik. (2013). Oral Stories. V.96 Astana: Foliant (kaz.) [] "Word of ancestors" One hundred tomnik - national wealth of the Kazakh people (2012). Уркер, Issue 9-10. P. 12-17 (kaz.).

[20] Zhansygiruly I. (1927). Iie. Moscow: Kunshygys (kaz.).

[21] Zhusipov B. (2009). Sea of poetry. Almaty: Arna-b (kaz.).

\section{ӘДЕБИЕТ}

[1] Алпысбаева Қ.Б., Ауесбаева П.Т. (2004). «Сейітбаттал» діни дастан нұсқаларының мәтіндік ерекшеліктері. ҚазҰУ Хабаршы - Шығыстану сериясы, 2, 13-18.

[2] Ауесбаева П.Т. (2014). Некоторые аспекты зачина в композиционном строе сказок тюркских народов: «История и культура народов Юго-Западной Сибири и сопредельных регионов (Казахстан, Монголия, Китай)». Материалы международной научно-практической конференции. - Горно-Алтайск, Республика Алтай, Россия. РИНЦ. (Б.71-74) (орысша); Морей ауданының ертегілері. (1999). China. Morey town. (қаз.).

[3] Әлбеков Т. (2011). Рухани қазынаның алтын көмбесі. Айқын.

[4] «Бабалар сөзі» жүз томдығы - қазақ халқының ұлттық байлығы (2012). Уркер. 9-10. Б. 12-17.

[5] Бабалар сөзі: Жүз томдық (2006). Батырлар жыры. Том 39. Астана: Фолиант.

[6] Бабалар сөзі: Жүз томдық (2012). Шежірелік жыр аңыздар. Том 81. Астана: Фолиант.

[7] Бабалар сөзі: Жүз томдық (2013). Хикаяттар. Том 95. Астана: Фолиант.

[8] Бабалар сөзі: Жүз томдық (2013). Ауызекі әңгімелер. Том 96. Астана: Фолиант.

[9] Ғабдуллин М. (1972). Қазақ халқының ауыз әдебиеті. Алматы: Ғылым.

[10] Albekov T.K., Alpysbayeva K.B., Auyesbayeva P.T. (2017). «Distinctive and educational features of Kazakh folklore by the example of «Words of Ancestors»»». Revista ESPACIOS. ISSN 07981015 (Web of Science). Vol. 38, Issue 45, 33-43

(ағылшын.).

[11]Жансүгірұлы І. (1927). Өтірік. Москва: Күншығыс.

[12] Жүсіпов Б. (2009). Жыр дастан. Алматы: Арна-б.

[13] Қазақ қолжазбаларының ғылыми сипаттамасы (1975-2013). Алматы: Ғылым.

[14] Қазақ мақал-мәтелдерінің түсіндірме сөздігі (2009). China: Xinjiang.

[15] Қазақ эпос мәселелері бойынша дискуссия (1953). Қазақ ССР бюллетені. 8. 97-98. 
[16] «Қарасай-Қази» жырының нұсқалық ерекшеліктері: Мұрын жырау және «Қырымның қырық батыры» жыры атты республикалық ғылыми-практикалық конференция (2013). Ақтау.

[17] Қасқабасов С. (2008). Этиологиялық ертегі. Қазақ әдебиетінің тарихы. Он томдық. 1-том. - Алматы: Қазақпарат.

[18 ]Қисса Қыз Жібек хикаясы (1900). Қазан.

[19] Құрышжанов А. (1987). Сөз атасы. Алматы: Ғылым.

[20] Тәуелсіздік идеясын жырлайтын қазақ эпостарының қолжазба нұсқалары (2011). Алматы: ID «CREDOS».

[21] Ісләмжанұлы К. (1995). Рухани уыз. Алматы: Ана тілі.

\section{ЛИТЕРАТУРА}

[1] Алпысбаева Қ.Б., Ауесбаева П.Т. (2004). Текстовые особенности вариантов религиозного дастана «Сейитбаттал». Вестник КазНУ - Серия Востоковедения, 2, 13-18 (каз.).

[2] Ауесбаева П.Т. (2014) Некоторые аспекты зачина в композиционном строе сказок тюркских народов: «История и культура народов Юго-Западной Сибири и сопредельных регионов (Казахстан, Монголия, Китай)». Материалы международной научно-практической конференции (71-74). Горно-Алтайск, Республика Алтай, Россия. РИНЦ (рус); Сказки Морейского района.- China. Morey town, 1999 (каз.).

[3] Албеков Т. Золотой клад духовного сокровища (2011). Айкын (каз.).

[4] Стотомник: «Слова предков» - национальная богатства казахского народа (2012) // Уркер. № 9-10. С. 12-17(каз.).

[5] Стотомник: Слова предков (2006). Героический эпос. Том. 39. Астана: Фолиант (каз.).

[6] Стотомник: Слова предков (2012). Генеологические поэмы и легенды. Том 81. Астана: Фолиант (каз.).

[7] Стотомник: Слова предков. (2013). Хикаяты. Том 95. Астана: Фолиант (каз.).

[8] Стотомник: Слова предков. (2013). Устные рассказы. Том 96. Астана: Фолиант (каз.).

[9] Albekov T.K., Alpysbayeva K.B., Auyesbayeva P.T. (2017). «Distinctive and educational features of Kazakh folklore by the example of «Words of Ancestors»»». Revista ESPACIOS. ISSN 07981015 (Web of Science). Vol. 38, Issue 45, 33-43

(англ.).

[10] Габдуллин М. (1972). Устная литература казахского народа. Алматы: Гылым (каз.).

[11] Жансугуров И. (1927). Ложь. Москва: Күншығыс (каз.).

[12] Жүсіпов Б. (2009). Жыр дастан. Алматы: Арна-б (каз.).

[13] Научное описание казахских рукописей (1975-2013). Алматы: Гылым (каз.).

[14] Толковый словарь казахских пословиц и поговорок. (2009). China: Xinjiang (каз.).

[15] Дискуссии по вопросам казахского эпоса (1953). Бюллетень КазССР. 8. С.97-98 (каз.).

[16] Особенности вариантов поэмы «Карасай-Кази»: Республиканская научно-практическая конференция «Мурын жырау и «Сорок воинов Кырыма» (2013). Актау (каз.).

[17] Каскабасов С. (2008). Этиологическая сказка. История казахской литературы. Десять томов. 1 том. Алматы: Казакпарат (каз.).

[18] Кисса Кыз Жибек хикаясы. (1900). Казань (каз.).

[19] Курышжанов А. (1987). Слово отца. Алматы: Гылым (каз.).

[20] Рукописи казахского эпоса, отражающие идею независимости (2011). Алматы: ID «CREDOS» (каз.).

[21] Сләмжанулы К. (1995). Рухани уыз. Алматы: Ана тили (каз.). 